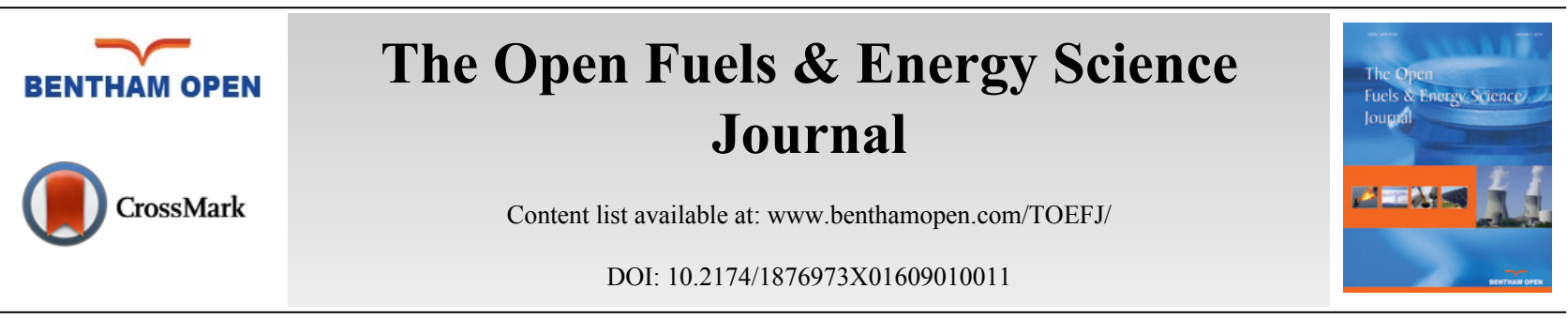

RESEARCH ARTICLE

\title{
Geochemistry of Elements in the Coal Seams of the Xishanyao Formation from Gashunwusan Mine, Xinjiang, Northwest China
}

\author{
Jinxi Wang ${ }^{1,2, *}$, Wenbo $\mathrm{Yao}^{2}$, Qi Wang ${ }^{2}$, Jianfei Zhou ${ }^{2}$ and Jiaolong $\mathrm{Li}^{2}$

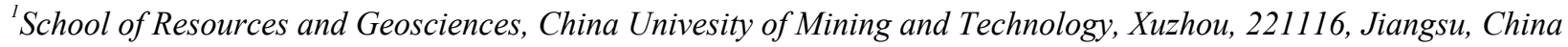 \\ ${ }^{2}$ Hebei Collaborative Innovation Center of Coal Exploitation, Hebei University of Engineering, Handan 056038, Hebei, \\ China
}

\begin{abstract}
The samples from Xishanyao Formation in Gashunwusan Mine were analysed by inductively coupled plasma massspectrometry (ICP-MS), X-Ray fluorimetry (XRF) and other techniques. Through the use of the above techniques, we researched characteristics and modes of occurrence of the trace elements. According to content and ratios of trace elements, we discussed coalforming environments of the research area. The results show that $\mathrm{Co}, \mathrm{Ga}, \mathrm{Sr}$, and $\mathrm{Ba}$ were slightly enriched in different coal seams in Xishanyao Formation in Gashunwusan Mine and total contents of trace elements were lower than the average values of Chinese and world coal. The common elements mainly contain $\mathrm{CaO}, \mathrm{SiO}_{2}, \mathrm{Al}_{2} \mathrm{O}_{3}$ and $\mathrm{Fe}_{2} \mathrm{O}_{3}$. The contents of above elements were low. Contents of $\mathrm{CaO}$ and $\mathrm{MgO}$ were higher than those in Chinese coal and US coal, while other elements were relatively depleted. There was a positive correlation between most of the trace elements and ash content. Modes of occurrence of most of trace elements were connected with inorganic mineral, which were effected considerably by terrestrial material. The values of $\mathrm{Sr} / \mathrm{Ba}, \mathrm{V} / \mathrm{Ni}$, and $\mathrm{V} / \mathrm{Zn}$ revealed that the sedimentary type of Jurassic coal seam in Gashunwusan Mine was the typical interior phase of lakes. The value $\mathrm{Ni} /$ Co revealed that the redox environment of coal-forming swamp was relatively weak.
\end{abstract}

Keywords: Coal, Geochemistry, Trace Elements, Xishanyao Formation.

\section{INTRODUCTION}

There are two directions for studying trace elements in coal: one is utilizing and recycling valuable elements, and the other is researching hazards to human health and the environment that are attracted by harmful elements. Abundances, modes of occurrence, and environmental effects of elements in coal in different areas and eras had been studied by many geologists [1 - 9]. Many human health problems in some areas of China are caused by harmful elements of coals. Sun [10] drew a new conclusion about the sources of the endemic fluorosis in Qianxi. Wang et al. [11] and Wang et al. [12] discussed modes of occurrence of harmful elements in coal. On the other hand, the content, enrichment mechanisms, and integrated utility indexes of associated metallic elements in Chinese coal have been reported in recent years [6,13-16]. Both environmental impacts and utilization of trace elements in coals are still hot research points $[6,13,17,18]$. However, geochemical studies about coal elements in China are focused on the central and eastern regions of China rather than coal basins and coalfields in the northwest of China at present.

Gashunwusan Mine is located in the east of Heshituoluogai Coalfield, which is very abundant in coal and is one of the most important coal production bases. However, research on geochemical characteristics of trace elements in this area is rarely reported. This paper focuses on Shanxiyao Formation in Gashunwusan Mine and discusses the coal forming environment and geochemistry characteristics of trace elements in this area.

\footnotetext{
* Address correspondence to this author at the School of Resources, Hebei University of Engineering, Handan, 056038, China; Tel: 0086-310-8579509; Fax: 0086-310-8578765; Email: jinxi77@126.com
} 


\section{GEOLOGICAL SETTING}

The study region is located west of Junggar basin, which is between Altay structural belt and North Tianshan structural belt. The coalfield lies north of the midpoint in Heshituoluogai Mesozoic's depression basin [19]. The terrain of this basin is broad and flat, slowly slanting from north to south. Heshituoluogai Depression is a multiple syncline, which is made of a series of anticline synclines in Fig. (1). The strata whose total thickness ranges from 359.66 to 385.99 meters has a comfortable contact with the underlying Sangonghe Formation [20]. Strata thickness tends to thin from west to east and coal seam spacing decreases from the west to the east. The middle Jurassic series in Xishanyao Formation is the main coal-bearing strata, deposited mostly from lacustrine facies, lacustrine-swamp facies, and lithology, which consists of mudstone, carbonaceous mudstone and sandstone with coal seam. There are 11-34 coal seams, total thickness of which is $12.79-37.88 \mathrm{~m}$. There are $7-13$ workable coal seams.

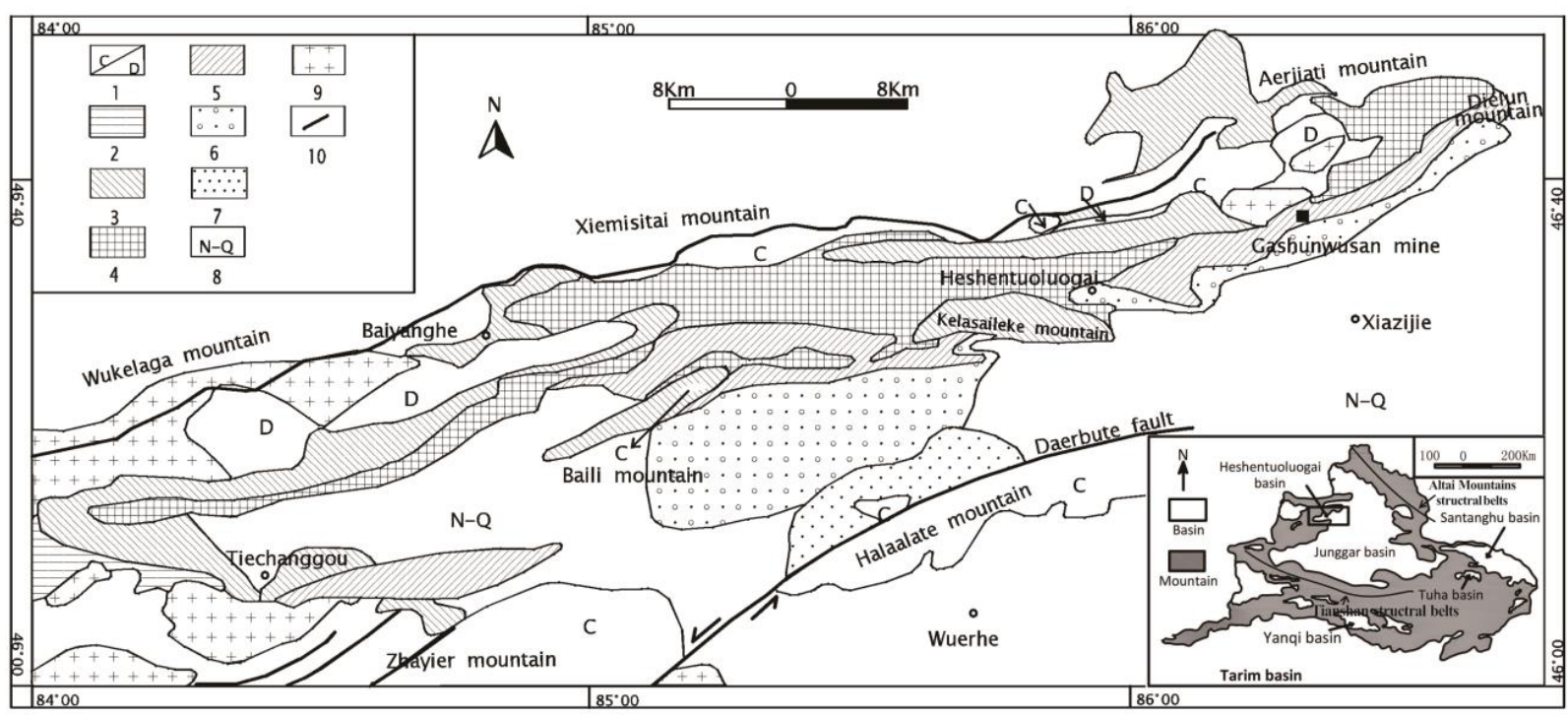

Fig. (1). Map showing the geology of Heshentuoluogai basin [20].

1-Carboniferous/Devonian; 2-Bailishan Formation (Late Triassic); 3-Badaowan Formation (Early Jurassic); 4Sangonghe Formation (Early Jurassic); 5-Xishanyao Formation (Middle Jurassic); 6-Toutunhe Formation (Middle Jurassic); 7-Tugulu Group (Early Cretaceous); 8-Caenozoic; 9-Late Paleozoic intrusive mass; 10-main basin2margin fault.

\section{SAMPLES AND METHODS}

Research samples were collected from Nos. B1, B2, B3, B4, B8, and B9 coal seams of Xishanyao Formation in Gashunwusan Coal Mine following Chinese Standard Method GB/T482-2008. Litholigical column is displayed in Fig. (2). By cutting from top to bottom, we acquired thirty-two samples, among which twenty-one were coal samples, and eleven came from the roof, floor and dirt band. Each sample was about $1 \mathrm{~kg}$ and was collected in a high strength bag to avoid pollution

After drying naturally, the samples were divided into two parts: one was the prepared sample, the other was the standby sample. The prepared samples were divided into two parts: one was crushed and grounded to 18 mesh, which was the amount of polished grain, and the other was grounded to $200 \mathrm{mesh}$, which was used in digestion experiment and XRF experiment. Contents of trace elements were determined by ICP-MS (inductively coupled plasma mass spectrometry). Contents of oxides of common elements in samples were determined by XRF (X-Ray Fluorescence), including $\mathrm{SiO}_{2}, \mathrm{Al}_{2} \mathrm{O}_{3}, \mathrm{Na}_{2} \mathrm{O}, \mathrm{MgO}, \mathrm{Fe}_{2} \mathrm{O}_{3}, \mathrm{P}_{2} \mathrm{O}_{5}, \mathrm{~K}_{2} \mathrm{O}, \mathrm{CaO}, \mathrm{TiO}_{2}$ and so on. Categories of mineral were determined by $\mathrm{X}$-ray powder diffractometer (power: $3 \mathrm{~kW}$, range of angle measurement: $3-70^{\circ}$; precision of angle measurement: $\left.\pm 0.02^{\circ}\right)$. 


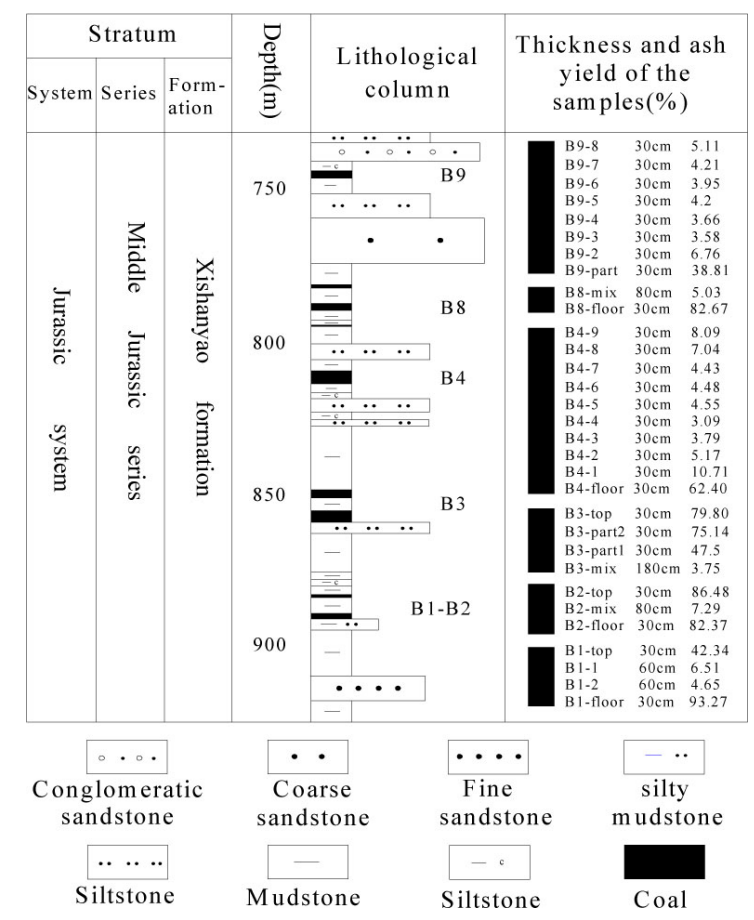

Fig. (2). Litholigical column of Xishanyao Formation.

\section{RESULTS AND DISCUSSION}

\subsection{Characteristics of Coal Property and Coal Petrology}

With large thickness, coal seams in Xishanyao Formation are stable. According to coal property analysis results (Table 1), coal properties of workable coal seams were similar. With moisture content of $8.54 \%$, volatile of $36 \%$, ash of $15 \%$, sulfur content less than $1 \%$, coal in this area has characteristics of low moisture coal, non-caking coal, low ash coal, and low sulfur coal. The values $\mathrm{H} / \mathrm{C}$ and $\mathrm{O} / \mathrm{C}$ are about 1 , which shows that coal in this area belongs to young low rank coal.

Table 1. The fundamental properties analysis of coal samples.

\begin{tabular}{|c|c|c|c|c|c|c|}
\hline \multicolumn{4}{|c|}{ Proximate analysis(\%) } & \multicolumn{3}{c|}{ Elemental analysis(\%) } \\
\hline $\mathrm{M}_{\mathrm{ad}}$ & $\mathrm{A}_{\mathrm{d}}$ & $\mathrm{Vd}_{\mathrm{af}}$ & $\mathrm{FC}_{\mathrm{d}}$ & $\mathrm{S}$ & $\mathrm{H} / \mathrm{C}$ & $\mathrm{O} / \mathrm{C}$ \\
\hline 8.54 & 15.22 & 35.59 & 40.65 & 0.74 & 0.96 & 1.08 \\
\hline
\end{tabular}

Maceral composition shows that coal maturity is low (Table 2). Vitrinite reflectance of each coal seam is less than $0.6 \%$. Vitrinite is the most content in maceral composition $(74.14 \%-86.2 \%$ averaged $76.6 \%)$. While, inertinite is less (9.2\%-23.63\%, with the average of $18.84 \%)$, and exinite is the least $(0.8 \%-4.36 \%$ with the mean value of $2.7 \%)$. The mineral content is in the range of $0.68 \%-3.80 \%$, averaged $1.88 \%$. Through analysis, the main mineral is aluminosilicate, quartz, etc.

Table 2. The maceral content and vitrinite reflectance in Xishanyao Formation.

\begin{tabular}{|c|c|c|c|c|c|}
\hline Coal seam & Vitrinite (\%) & Inertinite (\%) & Exinite (\%) & $\begin{array}{c}\text { Mineral } \\
\mathbf{( \% )}\end{array}$ & $\begin{array}{c}\text { Ro } \\
\text { (\%) }\end{array}$ \\
\hline B1 & 85.80 & 12.60 & 1.10 & 0.70 & 0.55 \\
\hline B2 & 86.20 & 9.20 & 0.80 & 3.80 & 0.55 \\
\hline B3 & 75.20 & 19.00 & 3.00 & 2.20 & 0.60 \\
\hline B4 & 75.44 & 17.36 & 4.36 & 2.87 & 0.56 \\
\hline B8 & 77.40 & 20.20 & 1.40 & 1.00 & 0.57 \\
\hline B9 & 74.14 & 23.63 & 1.43 & 0.68 & 0.58 \\
\hline
\end{tabular}




\subsection{Geochemistry Characteristics of Elements}

\subsubsection{Common Elements in Coal}

Compared with the arithmetic mean value of Chinese coal and US coal (Table 3) [6, 21], the content of $\mathrm{CaO}$ and $\mathrm{MgO}$ is higher in the coal of Gashunwusan Mine. Content of $\mathrm{P}_{2} \mathrm{O}_{5}$ is relatively enriched in some coal seams. Content of $\mathrm{Na}_{2} \mathrm{O}$ and $\mathrm{Fe}_{2} \mathrm{O}_{3}$ are also enriched in the bottom layers. The other elements belong to a relatively depleted type.

Table 3. The content of common elements and trace elements in Xishanyao Formation of Gashunwusan Mine ( $\mu \mathrm{g} / \mathrm{g})$.

\begin{tabular}{|c|c|c|c|c|c|c|c|c|c|c|}
\hline $\begin{array}{l}\text { Test } \\
\text { item }\end{array}$ & $\begin{array}{c}\text { Average of } \\
\text { B1 }\end{array}$ & $\begin{array}{c}\text { Average of } \\
\text { B2 }\end{array}$ & $\begin{array}{c}\text { Average of } \\
\text { B3 }\end{array}$ & $\begin{array}{c}\text { Average of } \\
\text { B4 }\end{array}$ & $\begin{array}{c}\text { Average of } \\
\text { B8 }\end{array}$ & $\begin{array}{c}\text { Average of } \\
\text { B9 }\end{array}$ & $\begin{array}{l}\text { Clark } \\
\text { value }\end{array}$ & Chinese coal & US coal & $\begin{array}{c}\text { World } \\
\text { coal }\end{array}$ \\
\hline $\mathrm{A}_{\mathrm{ad}} \%$ & 36.69 & 44.83 & 51.55 & 11.38 & 5.03 & 8.79 & nd & nd & nd & nd \\
\hline $\mathrm{SiO}_{2} \%$ & 22.16 & 25.98 & 23.94 & 4.74 & 0.85 & 3.10 & nd & 8.47 & 5.80 & nd \\
\hline $\mathrm{Al}_{2} \mathrm{O}_{3} \%$ & 7.76 & 11.06 & 10.07 & 2.73 & 0.75 & 1.64 & nd & 5.98 & 2.80 & nd \\
\hline $\mathrm{Fe}_{2} \mathrm{O}_{3} \%$ & 2.32 & 2.74 & 12.38 & 0.97 & 0.42 & 0.40 & nd & 4.85 & 1.90 & nd \\
\hline $\mathrm{CaO} \%$ & 1.14 & 1.17 & 1.15 & 1.12 & 1.76 & 1.97 & nd & 1.23 & 0.64 & nd \\
\hline $\mathrm{MgO} \%$ & 1.01 & 0.92 & 1.08 & 0.28 & 0.29 & 0.46 & nd & 0.22 & 0.18 & nd \\
\hline $\mathrm{K}_{2} \mathrm{O} \%$ & 0.97 & 1.10 & 1.01 & 0.25 & 0.01 & 0.17 & nd & 0.19 & 0.22 & nd \\
\hline $\mathrm{Na}_{2} \mathrm{O} \%$ & 0.25 & 0.13 & 0.25 & 0.07 & 0.03 & 0.03 & nd & 0.16 & 0.11 & nd \\
\hline $\mathrm{P}_{2} \mathrm{O}_{5} \%$ & 0.34 & 0.55 & 0.53 & 0.11 & 0.03 & 0.07 & nd & 0.092 & 0.098 & nd \\
\hline $\mathrm{Li}$ & 0.20 & 0.18 & 0.11 & 0.61 & 1.08 & 1.05 & 20.00 & 31.80 & 16.00 & 12.00 \\
\hline $\mathrm{Be}$ & 0.76 & 0.11 & 0.13 & 0.12 & 0.27 & 0.07 & 2.80 & 2.11 & 2.20 & 1.60 \\
\hline $\mathrm{V}$ & 10.20 & 6.32 & 3.62 & 13.22 & 9.60 & 10.40 & 135.00 & 35.10 & 22.00 & 25.00 \\
\hline $\mathrm{Cr}$ & 8.29 & 5.04 & 4.09 & 6.54 & 5.86 & 5.02 & 100.00 & 15.40 & 15.00 & 16.00 \\
\hline $\mathrm{Mn}$ & 194.13 & 79.05 & 42.03 & 36.50 & 42.44 & 87.30 & 950.00 & nd & nd & 85.00 \\
\hline $\mathrm{Co}$ & 6.26 & 1.03 & 5.35 & 0.87 & 10.43 & 5.24 & 25.00 & 7.08 & 6.10 & 5.10 \\
\hline $\mathrm{Ni}$ & 3.95 & 2.87 & 6.16 & 3.54 & 6.29 & 6.59 & 75.00 & 13.70 & 14.00 & 13.00 \\
\hline $\mathrm{Cu}$ & 9.34 & 10.30 & 8.69 & 12.60 & 8.37 & 8.70 & 55.00 & 17.50 & 16.00 & 16.00 \\
\hline $\mathrm{Zn}$ & 8.00 & 2.20 & 1.56 & 5.04 & 3.04 & 4.41 & 70.00 & 41.40 & 53.00 & 23.00 \\
\hline $\mathrm{Ga}$ & 7.03 & 9.54 & 0.92 & 7.34 & 3.94 & 4.10 & 15.00 & 6.55 & 5.70 & 5.80 \\
\hline $\mathrm{Rb}$ & 0.34 & 0.37 & 0.18 & 1.33 & 1.39 & 1.24 & 90.00 & 9.25 & 21.00 & 14.00 \\
\hline $\mathrm{Sr}$ & 181.75 & 205.22 & 41.10 & 238.66 & 176.14 & 257.62 & 375.00 & 140.00 & 130.00 & 110.00 \\
\hline $\mathrm{Ag}$ & 0.02 & 0.03 & 0.05 & 0.05 & 0.03 & 0.02 & 0.08 & nd & nd & nd \\
\hline $\mathrm{Cd}$ & 0.04 & 0.03 & 0.02 & 0.05 & 0.03 & 0.03 & 0.20 & 0.25 & 0.47 & 0.20 \\
\hline Cs & 1.01 & 0.03 & 0.01 & 0.14 & 0.12 & 0.03 & 3.00 & 1.13 & nd & 1.00 \\
\hline $\mathrm{Ba}$ & 154.56 & 268.00 & 15.44 & 192.04 & 94.44 & 108.33 & 425.00 & 159.00 & 170.00 & 150.00 \\
\hline $\mathrm{Tl}$ & 0.02 & 0.03 & 0.02 & 0.10 & 0.02 & 0.01 & 0.43 & 0.47 & 1.20 & nd \\
\hline $\mathrm{Pb}$ & 2.63 & 1.98 & 1.44 & 2.67 & 2.49 & 2.79 & 12.50 & 15.10 & 11.00 & 7.80 \\
\hline $\mathrm{Bi}$ & 0.02 & 0.02 & 0.02 & 0.03 & 0.02 & 0.02 & 0.17 & 0.79 & $<1.00$ & nd \\
\hline $\mathrm{U}$ & 0.17 & 0.04 & 0.02 & 0.10 & 0.09 & 0.08 & 2.70 & 2.43 & 2.10 & 2.40 \\
\hline $\mathrm{Sr} / \mathrm{Ba}$ & 1.18 & 0.77 & 2.66 & 1.24 & 1.87 & 2.38 & nd & nd & nd & nd \\
\hline $\mathrm{V} / \mathrm{Ni}$ & 2.58 & 2.20 & 0.59 & 3.73 & 1.53 & 1.58 & nd & nd & nd & nd \\
\hline $\mathrm{V} / \mathrm{Zn}$ & 1.28 & 2.87 & 2.32 & 2.62 & 3.16 & 2.36 & nd & nd & nd & nd \\
\hline $\mathrm{Ni} / \mathrm{Co}$ & 0.63 & 2.79 & 1.15 & 4.07 & 0.60 & 1.26 & nd & nd & nd & nd \\
\hline
\end{tabular}

nd (Not Detected).

\subsubsection{Trace Elements in Coal}

Compared with clark value [22], Chinese coal [6], and US coal [21], the contents of $\mathrm{Co}, \mathrm{Ga}, \mathrm{Sr}$, and $\mathrm{Ba}$ in Xishanyao Formation of Gashunwusan Mine is higher. Influenced by sedimentary microenvironment, the trace elements are not evenly distributed, even in the same coal seam. Fig. (3) shows that most trace elements are concentrated at the top, floor and parting samples. The distribution of $\mathrm{Li}, \mathrm{Be}, \mathrm{V}, \mathrm{Zn}, \mathrm{Tl}$, and $\mathrm{Pb}$ in $\mathrm{B} 4$, as well as vertical variation of $\mathrm{Be}, \mathrm{V}$, and $\mathrm{Pb}$ in $\mathrm{B} 9$ belong to the above situation. The causes of these differences may be influenced by the property of the parent rock, the chemical conditions of the coal-forming swamp, and the species of coal-forming plants, groundwater, etc [23]. At the beginning of accumulation of peat swamp, minerals and trace elements in the bottom of 
the swamp were affected by complex physical chemistry, biochemistry, and water, which mixed together in the swamp. As a consequence, the concentration of minerals and trace elements liters was high, which should be one of the reasons for high content of trace elements near the floor coal seam. When the top took shape, trace elements came into the swamp with provenance incessantly. With the changes of the geochemical environment, the swamp became unfavorable for the growth of vegetation. In this case, minerals and trace elements subsided and enriched. Obviously, contents of trace elements in coal were influenced by sediments at the top or on the floor.

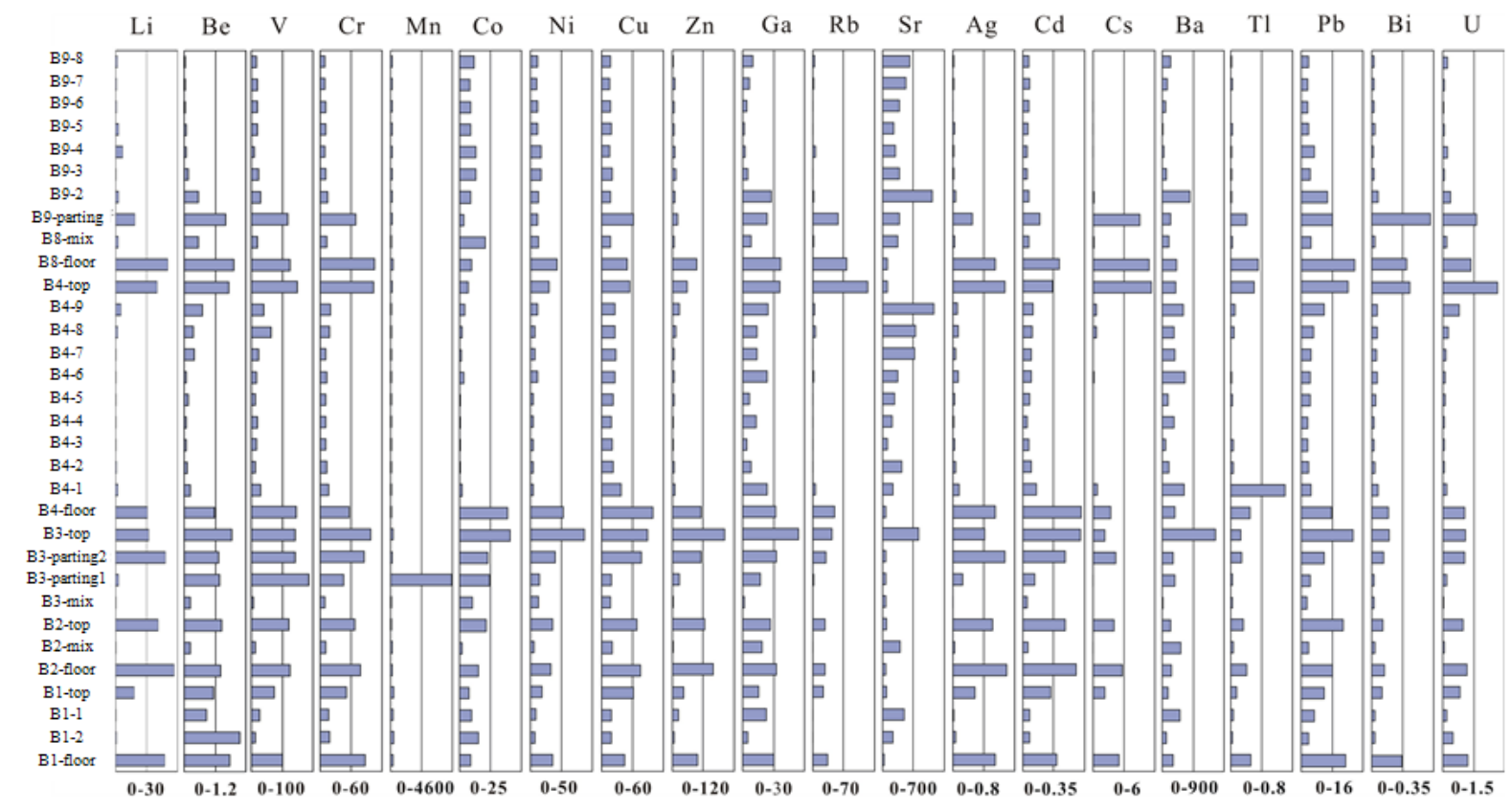

Fig. (3). The content distribution of 20 selected trace elements in the vertical section.

\subsubsection{Geochemical Characteristics of Rare Earth Elements}

Rare earth elements refer to lanthanide elements. Yttrium has similar properties with lanthanide. Thus, they are collectively called rare earth elements. Rare earth elements are composed of light rare earth elements and heavy earth elements. The former refers to total content of $\mathrm{La}-\mathrm{Eu}$, which is expressed in LREE. The latter refers to total content of La-Lu and Y, which is expressed in HREE Table 4.

Table 4. The geochemical parameters of rare earth elements $(\mu \mathrm{g} / \mathrm{g})$.

\begin{tabular}{|c|c|c|c|c|c|c|}
\hline Test item & B1 & B2 & B3 & B4 & B8 & B9 \\
\hline $\mathrm{La}$ & 7.36 & 2.74 & 0.91 & 3.21 & 4.72 & 3.78 \\
\hline $\mathrm{Ce}$ & 12.08 & 5.45 & 1.94 & 6.39 & 7.99 & 7.82 \\
\hline $\mathrm{Pr}$ & 1.44 & 0.67 & 0.26 & 0.83 & 1.31 & 0.82 \\
\hline $\mathrm{Nd}$ & 7.06 & 3.2 & 1.37 & 3.89 & 6.18 & 3.37 \\
\hline $\mathrm{Sm}$ & 1.36 & 0.65 & 0.36 & 0.8 & 1.38 & 0.62 \\
\hline $\mathrm{Eu}$ & 0.42 & 0.37 & 0.11 & 0.32 & 0.37 & 0.2 \\
\hline $\mathrm{Gd}$ & 1.41 & 0.7 & 0.42 & 0.78 & 1.45 & 0.63 \\
\hline $\mathrm{Tb}$ & 0.2 & 0.1 & 0.07 & 0.12 & 0.22 & 0.09 \\
\hline $\mathrm{Dy}$ & 1.15 & 0.56 & 0.45 & 0.68 & 1.26 & 0.52 \\
\hline $\mathrm{Ho}$ & 0.25 & 0.12 & 0.1 & 0.14 & 0.26 & 0.1 \\
\hline $\mathrm{Er}$ & 0.78 & 0.35 & 0.28 & 0.41 & 0.78 & 0.3 \\
\hline $\mathrm{Tm}$ & 0.11 & 0.05 & 0.04 & 0.06 & 0.1 & 0.04 \\
\hline $\mathrm{Yb}$ & 0.75 & 0.3 & 0.23 & 0.39 & 0.73 & 0.27 \\
\hline $\mathrm{Lu}$ & 0.12 & 0.04 & 0.03 & 0.06 & 0.11 & 0.04 \\
\hline $\mathrm{NREE}$ & 34.45 & 15.3 & 6.57 & 18.09 & 26.86 & 18.6 \\
\hline $\mathrm{LREE}$ & 29.71 & 13.08 & 4.95 & 15.45 & 21.95 & 16.62 \\
\hline $\mathrm{HREE}$ & 4.75 & 2.22 & 1.62 & 2.64 & 4.91 & 1.98 \\
\hline
\end{tabular}


(Table प) contd....

\begin{tabular}{|c|c|c|c|c|c|c|}
\hline Test item & B1 & B2 & B3 & B4 & B8 & B9 \\
\hline L/HREE & 7.13 & 5.89 & 3.06 & 5.96 & 4.47 & 8.84 \\
\hline $\mathrm{La}_{\mathrm{N}} / \mathrm{Yb}_{\mathrm{N}}$ & 13.05 & 6.17 & 2.67 & 5.74 & 4.37 & 10.14 \\
\hline $\mathrm{La}_{\mathrm{N}} / \mathrm{Sm}_{\mathrm{N}}$ & 2.61 & 2.65 & 1.59 & 2.84 & 2.15 & 3.98 \\
\hline $\mathrm{Gd}_{\mathrm{N}} / \mathrm{Lu}_{\mathrm{N}}$ & 2.58 & 2.18 & 1.74 & 1.65 & 1.64 & 2.13 \\
\hline$\delta \mathrm{Eu}$ & 0.9 & 1.68 & 0.86 & 1.45 & 0.8 & 0.92 \\
\hline$\delta \mathrm{Ce}$ & 0.88 & 0.94 & 0.93 & 0.91 & 0.75 & 1.03 \\
\hline$\delta \mathrm{Ce} / \delta \mathrm{Eu}$ & 0.99 & 0.56 & 1.08 & 0.69 & 0.94 & 1.16 \\
\hline
\end{tabular}

There are many geochemical parameters of rare earth elements, but $\sum R E E$, LREE, HREE, LREE/HREE, $(\mathrm{La} / \mathrm{Yb})_{\mathrm{N}}$, $\delta \mathrm{Eu}$ and $\delta \mathrm{Ce}$ are commonly used to reflect the characteristics of rare earth elements [24]. $\sum \mathrm{REE}$ reflects the total content of rare earth elements, LREE reflects the content of light rare earth elements, HREE reflects the content of heavy rare earth elements and LREE/HREE reflects the degree of enrichment of light rare earth element and heavy rare earth elements. The ratio is small, which means relatively depletion of light rare earth elements. $\delta$ Eu and $\delta C e$ reflect the extent of the $\mathrm{Eu}$ and $\mathrm{Ce}$ anomaly reaction. Usually, 1 is the dividing line: the ratio greater than 1 indicates positive anomaly, otherwise, the negative anomaly.

The average value of $\sum$ REE in each coal seam of Gashunwusan Mine ranges from 6.57 to $34.45 \mu \mathrm{g} / \mathrm{g}$, which is almost a tenth to a third of the world's coal $(68.5 \mu \mathrm{g} / \mathrm{g})[25]$ and far lower than the Chinese average value $(137.9 \mu \mathrm{g} / \mathrm{g})$ [6] while basically remaining within Chinese coal range.

LREE concentration of all samples ranges from $4.95 \mu \mathrm{g} / \mathrm{g}$ to $29.71 \mu \mathrm{g} / \mathrm{g}$, HREE concentration varies from $1.62 \mu \mathrm{g} / \mathrm{g}$ to $4.91 \mu \mathrm{g} / \mathrm{g}$. The average value of LREE/HREE in each coal seam ranges from 3.06 to $4.91 \mu \mathrm{g} / \mathrm{g}$, which indicates LREE obviously concentrated.

HREE shows a relatively depleted type. $\delta$ Eu reflects the degree of anomaly (Table 4), which is less than 1 in coal seams B1, B3, B8, and B9. These samples show negative anomaly, while in B2 and B4 coal seams, there is a slightly positive anomaly. The research suggests that anomaly of $\mathrm{Eu}$ is influenced by continental matrix and redox properties of aqueous media during the time that coal seam is deposited in swamps. The stronger the reductibility is, the more obvious the negative anomaly is, which suggest a weak redox coal-forming environment. $\delta \mathrm{Ce}$ in each coal seam varies from 0.88 to $1.03 \mu \mathrm{g} / \mathrm{g}$ (Table 4), which shows slight depletion or no anomaly.

After standardization by average of upper crust [26], the distribution patterns of rare earth elements in samples is shown below Fig. (4), from which we can see that distribution patterns are basically in accordance with each other. All of them slant rightwards. From La to Lu, standardized values of rare earth elements increase gradually, with a notable rise at the point of $\mathrm{Eu}$. The left of the distribution curve is high, and the right is low; it looks like a " $\Lambda$ " as a whole. The La-Sm curve is steep, and its slop is higher. However, the La-Sm curve is flat and has a lower slop. Eu presents with a "hill" in the curve. The fractionation degrees of light and heavy rare earth elements are different; the former is higher.

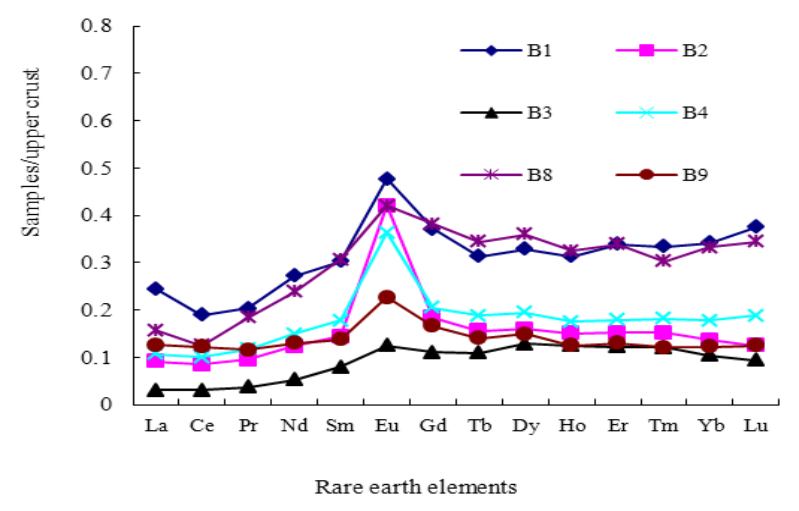

Fig. (4). Distribution patterns of rare earth elements in Gashunwusan Mine.

\subsection{Correlation Analysis About Trace Elements and Ash Content}

Using the mathematical statistics method, we analyzed correlation between trace elements and ash content, which 
revealed some information about organic and inorganic affinity of trace elements [27]. Significant positive correlations mean trace elements occur inorganically in coal. Otherwise, they have affinities with organic maceral.

According to the correlation coefficient, we can see most of the trace elements show positive correlations with ash content. $\mathrm{A}_{\mathrm{ad}}$ (ash content) shows highly positive correlations with $\mathrm{Cd}(0.94), \mathrm{Cs}(0.92), \mathrm{Rb}(0.89), \mathrm{Cu}(0.83), \mathrm{Tl}(0.80)$ and $\mathrm{Bi}(0.80$. What's more, ash content has significant positive correlations with $\mathrm{Li}(0.70), \mathrm{Cr}(0.79), \mathrm{Ag}(0.78), \mathrm{Zn}$ (0.64), Ga (0.64), Ba (0.59), Pb (0.54), V (0.53), U (0.52) and Be (0.52). It shows lower correlations with other elements. Mn is the only element that has negative correlation with ash content. All of the above shows that most of the trace elements are concentrated in inorganic minerals.

Rare earth elements in coal mainly combine with silicate minerals in general, the source of which mostly are terrigenous clast and liquor. The content of rare earth elements mainly depends on inorganic components [28]. In addition, rare earth elements also can combine with organic components. As shown in Fig. (5), rare earth elements in Gashunwusan Mine have significant correlation with ash content. Their correlation coefficients in B4 and B9 are 0.49 and 0.62 , indicating that rare earth elements are mainly concentrated in minerals. They also have strong correlation with $\mathrm{Al}_{2} \mathrm{O}_{3}$ and $\mathrm{SiO}_{2}$, which means clay mineral may be their carrier.

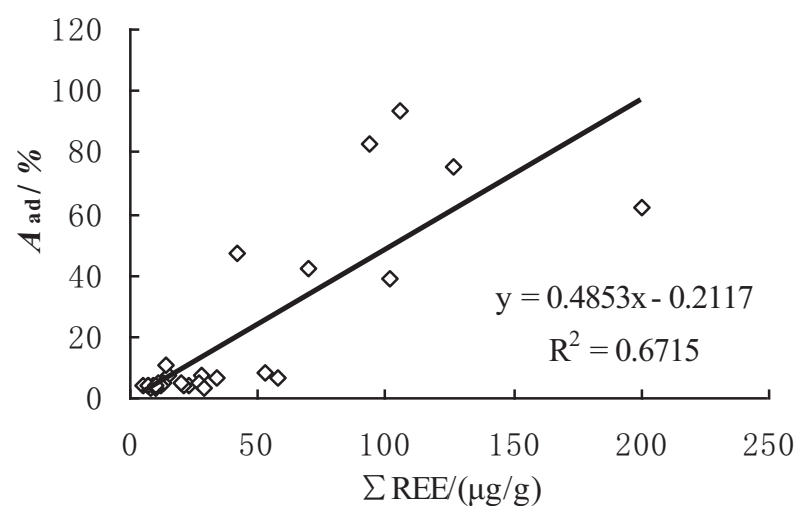

Fig. (5). Relationship between ash and $\Sigma$ REE of coals in Gashunwusan Mine.

The samples were analyzed by XRD and other techniques (Fig. 6). The results showed that main minerals in the dirt band were quartz, kaolinite, illite, polylithionite, clinochlore etc. The content of trace elements is influenced by the seam roof, floor and dirt band as well as terrigenous materials. This is because in or after the process of coal seams formation, the elements in seam roof, floor and dirt band came into coal seam along with water circulation, and regenerated secondary minerals or combined with organic materials through complicated physical, chemical and biological function, concentrated in coal at last.

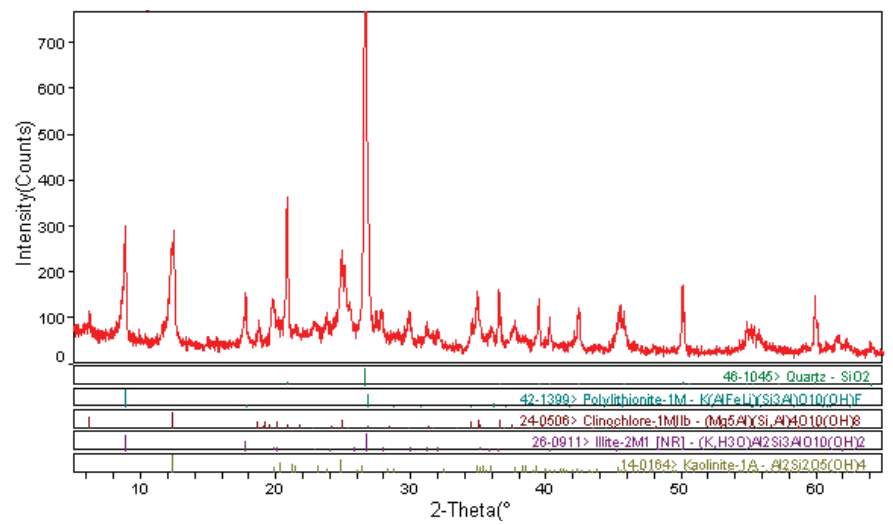

Fig. (6). XRD pattern of the dirt band in Xishanyao Formation. 


\subsection{Environmental Significance of Trace Elements}

Distribution characteristic of trace elements in coal is closely related to sedimentary environment. Therefore, geochemical characteristics and ratios of some trace elements have been indicators of coal seam sedimentary environment. Sr, Ba, B, Th, U, Ga, V, Ni, Co and other elements are often considered sensitive to their environment [29]. They can be used to not only distinguish seawater from fresh water sediment, but also reflect paleosalinity of aqueous medium and redox conditions. The research data shows that continental elements include elements such as $\mathrm{Ba}$, $\mathrm{Ga}, \mathrm{Zr}, \mathrm{Ti}$, Th and $\mathrm{Zn}$. Thalassophile elements include $\mathrm{Sr}, \mathrm{B}, \mathrm{V}, \mathrm{Ni}, \mathrm{Cu}$ and so on [29].

\subsubsection{Common Elements}

Geochemical parameters of common elements show medium conditions of peat accumulation period. However, it must be used in the same conditions of metamorphic grade and in similar ash content [30]. In this research, samples were taken from the same mine and the same formation, with the same metamorphic grade and similar ash content scope to satisfy above conditions.

Phosphate mainly forms iron phosphate in fresh water environment and calcium phosphate in saline water environment. That is why $\mathrm{CaO} /\left(\mathrm{Fe}_{2} \mathrm{O}_{3}+\mathrm{CaO}\right)$ is used to estimate salinity of sedimentary water medium, with high value indicating high salinity. Table 5 reflects the salinity of sedimentary water medium as it increases from B1 to B9.

Table 5. The parameters of constant elements in geochemical characteristics.

\begin{tabular}{|c|c|c|c|c|c|c|}
\hline Coal seam number & B1 & B2 & B3 & B4 & B8 & B9 \\
\hline $\mathrm{CaO} /\left(\mathrm{Fe}_{2} \mathrm{O}_{3}+\mathrm{CaO}\right)$ & $\frac{0.46 \sim 0.52}{0.49}$ & 0.54 & 0.62 & $\frac{0.23 \sim 0.78}{0.62}$ & 0.81 & $\frac{0.78 \sim 0.93}{0.85}$ \\
\hline
\end{tabular}

\subsubsection{Trace Elements}

Content of Co is used to confirm types of swamp, the values of $\mathrm{Sr} / \mathrm{Ba}, \mathrm{V} / \mathrm{Ni}$ and $\mathrm{V} / \mathrm{Zn}$ are used to confirm salinity of sedimentary water medium, and the value of $\mathrm{Ni} / \mathrm{Co}$ is used to confirm types of redox in this study [31, 32]. Basin swamp from intermediate swamp (B1) rose to raised swamp (B2) and then lowered to intermediate swamp (B3). Afterwards, from raised swamp (B4), it lowered to low-level swamp (B8), and then rose to intermediate swamp (B9). The changing process was indicated by the content of Co. In general, the swamp that stayed at high level received less provenance clastic. Xishanyao Formation in Gashunwusan Mine basically stayed in intermediate and raised swamp, which may be why content of trace elements is less. The values of $\mathrm{Sr} / \mathrm{Ba}, \mathrm{V} / \mathrm{Ni}$, and $\mathrm{V} / \mathrm{Zn}$ reflected that salinity of sedimentary water medium is large. Jurassic coal seams were deposited in an inland lake, the reasons of which may be changes of climate, leading to water salinization in the basin swamp [33]. The value of $\mathrm{Ni} / \mathrm{Co}$ is smaller in enriched oxygen sediment than in low oxygen sediment [34], making it a possible indicator of oxygen enrichment degree. The value in this study shows that coal-forming swamp was in relatively weak redox environment.

\subsection{3. $\delta E u$}

$\delta$ Eu reflects the extent of Eu abnormal valence reaction. Generally, rare earth elements mainly have charge of plus three; seldom could they change valences. However, in acid medium or under strong reduction condition, $\mathrm{Eu}^{3+}$ is reduced to $\mathrm{Eu}^{2+}$, which makes it separate from other trivalency rare earth elements. Thus, negative anomaly of $\delta \mathrm{Eu}$ indicates an acid or reduction environment. $\delta \mathrm{Eu}$ in coal seam of Xishanyao Formation Gashunwusan Mine ranges from 0.69 to 2.31 , which in B3 (0.86), B8 (0.80), and B9 (0.92) shows a slightly negative anomaly. At the top, floor and parting, samples range from 0.67 to 0.99 , indicating mild to moderate negative anomaly. Study suggests that negative anomaly of $\mathrm{Eu}$ is influenced by terrigenous parent rock and redox of water medium when coal seam is deposited. Negative anomaly of Eu increases when reduction condition gets stronger, which indicates the redox of coal forming environment was weak.

\section{CONCLUSION}

1. Comparing with contents of elements in Chinese coal, US coal and world coal, $\mathrm{Co}, \mathrm{Ga}, \mathrm{Sr}$, and $\mathrm{Ba}$ in different coal seams are slightly enriched, and the overall content of trace elements is low in Xishanyao Formation, Gashunwusan Mine. The content of common elements is low, and it mainly contains $\mathrm{CaO}, \mathrm{SiO}_{2}, \mathrm{Al}_{2} \mathrm{O}_{3}$ and $\mathrm{Fe}_{2} \mathrm{O}_{3}$. Among them, content of $\mathrm{CaO}$ and $\mathrm{MgO}$ is higher than that in Chinese coal and US coal, while other elements are relatively depleted. 
2. Content of rare earth elements is low. $\Sigma$ REE concentrations of all samples range from $10.34 \mu \mathrm{g} / \mathrm{g}$ to 415.65 $\mu \mathrm{g} / \mathrm{g}$, HREE ranges from 1.62 to $4.91 \mu \mathrm{g} / \mathrm{g}$, LREE/HREE ranges from 3.06 to $8.84 \mu \mathrm{g} / \mathrm{g}$, which indicates a high concentration of LREE, and HREE is relatively depleted. The highest value of $\delta$ Eu is lower than 1 , which reveals a negative anomaly in $\mathrm{Eu}$, while in B2(1.68) and B4(1.45), Eu shows a slightly positive anomaly. $\delta \mathrm{Ce}$ ranges from 0.75 to $1.13 \mu \mathrm{g} / \mathrm{g}$, which means $\mathrm{Ce}$ is normal or has a slightly negative anomaly.

3. The ratios of $\mathrm{Sr} / \mathrm{Ba}, \mathrm{V} / \mathrm{Ni}$ and $\mathrm{V} / \mathrm{Zn}$ reveal that Jurassic coal seams were deposited in an inland lake. The ratio of $\mathrm{Ni} / \mathrm{Co}$ shows that coal-forming swamp was in a relatively weak redox environment.

\section{CONFLICT OF INTEREST}

The authors confirm that this article content has no conflicts of interest.

\section{ACKNOWLEDGEMENTS}

This study was financially supported by the National Science Fundamental of China Projects (Nos. 41330317 and 41440019) and by the project of the Science Foundation of Hebei (No.D2013402021).

\section{REFERENCES}

[1] Finkelman, R.B. Modes of occurrence of environmentally-sensitive trace elements of coal. In: Environmental Aspects of Trace Elements of Coal; Swaine, D.J.; Goodarzi, F., Eds.; Kluwer Academic Publishers: Dordrecht, 1995; pp. 24-50.

[http://dx.doi.org/10.1007/978-94-015-8496-8_3]

[2] Finkelman, R.B.; Orem, W.; Castranova, V.; Tatu, C.A.; Belkin, H.E.; Zheng, B.; Lerch, H.E.; Maharaj, S.V.; Bates, A.L. Health impacts of coal and coal use: possible solutions. Int. J. Coal Geol., 2002, 50, 425-443. [http://dx.doi.org/10.1016/S0166-5162(02)00125-8]

[3] Bai, X.F. The Distributions, Modes of Occurrence and Volatility of Trace Elements in Coals of China, Doctoral Thesis, China Coal Science Research Institute: Beijing, China, 2003., 21-22. (in Chinese with English abstract)

[4] Tang, X.Y.; Huang, W.H. Trace Elements in China Coal; The Commercial Press: Beijing, 2004, pp. 3-11. (in Chinese with English abstract)

[5] Ren, D.; Zhao, F.; Dai, S.; Zhang, J.; Luo, K. Geochemistry of Trace Elements in Coal; Science Press: Beijing, 2006, p. 556. (in Chinese with English abstract)

[6] Dai, S.F.; Ren, D.Y.; Chou, C.L.; Finkelman, R.B.; Seredin, V.V.; Zhou, Y.P. Geochemist of trace elements in Chinese coals: A review of abundances, genetic types, impacts on human health, and industrial utilization. Int. J. Coal Geol., 2012, 94(1), 3-21. [http://dx.doi.org/10.1016/j.coal.2011.02.003]

[7] Sun, Y.Z.; Zhao, C.L.; Li, Y.H.; Wang, J.X.; Liu, S.M. Li distribution and mode occurrences in Li-bearing coal seam \#6 from the Guanbanwusu Mine, Inner Monggolia, northern China. Int. J. Coal Geol., 2012, 30(1), 109-130.

[8] Zhuang, X.G.; Wang, P.; Zhou, J.B.; Li, J. Geochemical characteristics of coal in Zhundong coal mining district. Xinjiang Geology, 2013, 31(1), 94-98. [in Chinese with English abstract].

[9] Zhao, C.L.; Sun, Y.Z.; Xiao, L.; Qin, S.J.; Wang, J.X.; Duan, D.J. The occurrence of barium in a Jurassic coal in the Huangling 2 Mine, Ordos Basin, northern China. Fuel, 2014, 128, 428-432. [http://dx.doi.org/10.1016/j.fuel.2014.03.040]

[10] Sun, Y.Z. Geochemistry study of fluorine in coal and coal-burning fluorosis. Bull. Mineral. Petrol. Geoch., 2005, 24(4), $350-356$.

[11] Wang, W.F.; Qin, Y.; Song, D.Y. The modes of occurrence of harmful trace elements in coal. Coal Geol. China, 2003, 15(4), 10-13.

[12] Wang, J.X.; Ling, P.; Yang, J.J.; Zhao, J. Geochemical characteristics of hazardous trace elements in the coal from the Pingshuo mine district, China. World J. Eng., 2013, 10(5), 463-470. [http://dx.doi.org/10.1260/1708-5284.10.5.463]

[13] Seredin, V.V.; Dai, S.F.; Sun, Y.Z.; Chekryzhov, I.Y. Coal deposits as promising sources of rare metals for alternative power and energyefficient technologies. Appl. Geochem., 2013, 31, 1-11. [http://dx.doi.org/10.1016/j.apgeochem.2013.01.009]

[14] Sun, Y.Z.; Li, Y.H.; Zhao, C.L.; Lin, M.Y.; Wang, J.X.; Qin, S.J. Concentrations of lithium in chinese coals. Energy Explor. Exploit., 2010, 28(2), 97-104. [http://dx.doi.org/10.1260/0144-5987.28.2.97]

[15] Sun, Y.Z.; Zhao, C.L.; Li, Y.H.; Wang, J.X.; Zhang, J.Y.; Jin, Z.; Lin, M.Y. Further information of the associated Li deposits in the No.6 Coal Seam at Jungar Coalfield, Inner Mongolia, northern China. Acta Geol. Sin., 2013, 87(4), 1097-1108. a [http://dx.doi.org/10.1111/1755-6724.12112]

[16] Sun, Y.Z.; Zhao, C.L.; Li, Y.H.; Wang, J.X. Minimum mining grade of the selected trace elements in Chinese coal. J. China Coal Society, 2014, 39(4), 744-748. [in Chinese with English abstract].

[17] Sun, Y.Z.; Zhao, C.L.; Zhang, J.Y.; Yang, J.J.; Zhang, Y.Z.; Yuan, Y.; Xu, J.; Duan, D.J. Concentrations of valuable elements of the coals 
from the Pingshuo Mining District, Ningwu Coalfield, northern China. Energy Explor. Exploit., 2013, 31(5), 727-744. b [http://dx.doi.org/10.1260/0144-5987.31.5.727]

[18] Chu, G.C.; Xiao, L.; Jin, Z.; Lin, M.Y.; Blokhin, M.G. The relationship between trace element concentrations and coal-forming environments in the No.6 coal seam, Haerwusu Mine, China. Energy Explor. Exploit., 2015, 33(1), 67-74. [http://dx.doi.org/10.1260/0144-5987.33.1.91]

[19] Li, S. Fault-Basin Analysis and Coal Accumulating Law; Geological Publishing House: Beijing, 1988.

[20] Qu, H.J.; Hu, J.M.; Li, W.; Gao, S.L.; Zhang, Y.L.; Liu, J.; Cui, J.J. The characteristics of sedimentation and tectonic evolution of heshentuoluogai basin in early mesozoic, northwest xinjiang. Acta Geol. Sin., 2008, 82(4), 441-450. [in Chinese with English abstract].

[21] Finkelman, R.B. Trace and Minor Elements in Coal. In: Organic Geochemistry; Plenum: New York, 1993 ; pp. $593-607$.

[22] Li, T. Element abundances of Chinese continental crust and its sedimentary layer and upper continental crust. Geochemica, 1994, 23(2), 140-145. [in Chinese with English abstract].

[23] Sun, Y.Z.; Zhao, C.L.; Li, Y.H.; Wang, J.X. Anomalous concentrations of rare metal elements, rare-scattered (dispersed) elements and rare earth elements in the coal from iqe coalfield, qinghai province, china. Acta. Geol. Sin., 2015, 89(1), 229-241. [http://dx.doi.org/10.1111/1755-6724.12407]

[24] Zhao, C.L.; Duan, D.J.; Li, Y.H.; Zhang, J.Y. Rare earth elements in No.2 coal of Huangling mine, Huanglong coalfield, China. Energy Explor. Exploit., 2012, 30(5), 803-818. [http://dx.doi.org/10.1260/0144-5987.30.5.803]

[25] Ketris, M.P.; Yudovich, Y.E. Estimations of Clarkes for carbonaceous biolithes: world average for trace element contents in black shales and coals. Int. J. Coal Geol., 2009, 78, 135-148. [http://dx.doi.org/10.1016/j.coal.2009.01.002]

[26] Taylor, S.R.; McLennan, S.M. The Continental Crust: Its Composition and Evolution; Blackwell: Oxford, 1985.

[27] Kortenski, J.; Sotirov, A. Trace and major element content and distribution in Neogene lignite from the Sofia Basin, Bulgaria. Int. J. Coal Geol., 2002, 52(1-4), 63-82. [http://dx.doi.org/10.1016/S0166-5162(02)00133-7]

[28] Zhao, C.L.; Sun, Y.Z. Rare earth elements of Coal Seam 5 from Gequan Mine, Xingtai Coalfield. World J. Eng., 2008, 5(1), 90-94.

[29] Qin, Y.; Wang, W.F.; Song, D.Y.; Zhang, X.D. Geochemistry characteristics and sedimentary micro-environments of No.11 coal seam of the Taiyuan Formation of Upper Carboniferous in Pingshuo Mining District, Shanxi Province. J. Palaeogeogr., 2005, 7(2), 249-260. [in Chinese with English abstract].

[30] Wu, C.D.; Xu, Y.L.; Guo, Z.J.; Quan, S.J.; Li, Y.L.; Feng, X. Geochemistry characteristics and palaeogeographic significance of Jurassic coal seam in Yanqi Basin of Xinjiang. Prog. Nat. Sci., 2006, 16(2), 199-206. [in Chinese with English abstract].

[31] Liu, H.J.; Zhang, Y.J.; Wang, H.W. Palaeogeography Study of Coal Bearing Formation Lithofacies in Jungar Coal Fields; Geological Publishing House: Beijing, 1991, pp. 1-128. (in Chinese with English abstract)

[32] Tu, G.C. Geochemistry; Shanghai Scientific and Technical Publishers: Shanghai, 1982, pp. 190-243. (in Chinese)

[33] Wang, J.X.; Deng, X.L.; Kalkreuth, W. The distribution of trace elements in various peat swamps of the No.11 coal seam from the Antaibao Mine, Ningwu coalfield, China. Energy Explor. Exploit., 2011, 29(4), 517-524. [http://dx.doi.org/10.1260/0144-5987.29.4.517]

[34] Jones, B.; Manning, D.A. Comparison of geochemical indicies used for the interpretation of palaeoredox conditions in ancient mudstones. Chem. Geol., 1994, 111(1-4), 111-129. [http://dx.doi.org/10.1016/0009-2541(94)90085-X]

(C) Wang et al.; Licensee Bentham Open.

This is an open access article licensed under the terms of the Creative Commons Attribution-Non-Commercial 4.0 International Public License (CC BY-NC 4.0) (https://creativecommons.org/licenses/by-nc/4.0/legalcode), which permits unrestricted, non-commercial use, distribution and reproduction in any medium, provided the work is properly cited. 